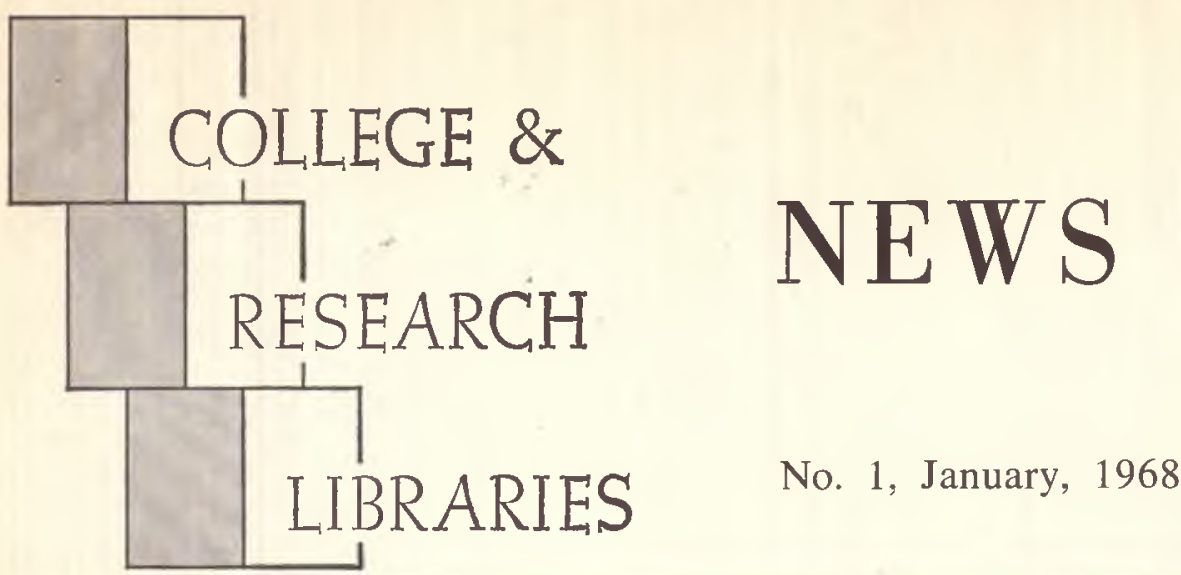

ACRL News Issue (A) of College \& Research Libraries, Vol. 29, No. 1

\title{
Fifty-third Conference of Eastern College Librarians
}

Some three hundred academic librarians made their annual post-Thanksgiving trek to Harkness Theater in the Butler library at Columbia University on November 25 for the fifty-third Conference of Eastern College Librarians. The program, which concerned "National Resources for College and Research Libraries," was ably prepared and graciously chaired by Irlene Roemer Stephens of Richmond College. Other members of the Committee were James Govan (Swarthmore), Robert Palmer (Barnard), and Paul Kebabian (University of Vermont).

At the morning session the group heard presentations concerning federal library services to academic libraries. Paul Berry spoke for the Library of Congress; Patricia Condon described the services of the National Agricultural Library, where she is assistant program coordinator; Scott Adams, deputy director of the National Library of Medicine, told of NLM; and Russell Shank, director of the Smithsonian Institution library, defined the work of his agency.

Emphasizing how the new has grown naturally from the old at LC, Mr. Berry used as examples: the recent expansion of printed card service under the Title II-C acquisitions program; traditional interlibrary loan developing into modern photocopy service; the bibliography publication program culminating after a century and a half in the current preparation for the press of the retrospective National Union Catalog.
Among other new programs, he described Machine Readable Cataloging (MARC); the National Science and Technology Referral Center; and the Library of Congress Automation Technique Exchange (LOCATE).

Looking to the future, Mr. Berry told of three important potentialities under the amendments to the Higher Education Act. These are: (1) the acquisition of second copies of Title II-C books to be deposited in the Center for Research Libraries; (2) the extension of bibliographic services associated with II-C acquisitions; and (3) the supplying to local libraries of assistance in acquiring books from countries lacking a developed book trade. He also described aspirations to establish a MARC-type project for serials data and to gain better bibliographical control over, and to participate in the distribution of, non-GPO documents.

Miss Condon of the National Agriculture Library, answered the question "What is it?" by describing its history and the scope of its current services. In answering the question "What does it do?" she pointed out that it distributes its services to the entire agricultural-biological research community. When asked "What services does it offer?" she replied that it rendered interlibrary loan and photocopy services, maintained an open-stack collection, published lists of its new acquisitions and other bibliographies, and rendered mail-order refer- 


\section{for better service...}

\section{Liberal Terms}

.. send for our current discount schedule

\section{Efficient Order-Handling}

. . . alert, experienced personnel

\section{Huge Inventory}

. . in our own warehouses

\section{Speedy Delivery}

... your order processed without delay
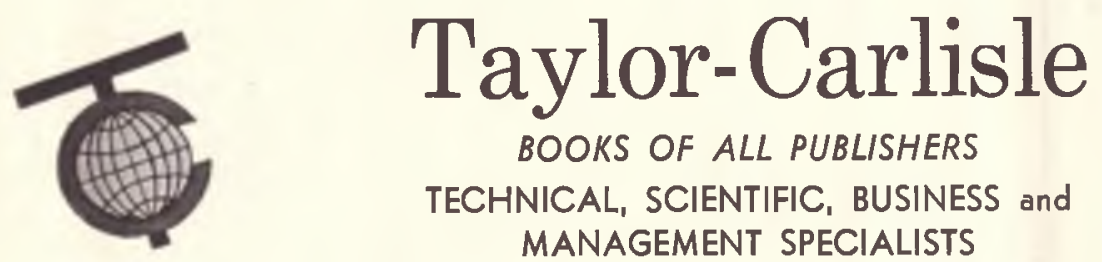

BOOKS OF ALL PUBLISHERS

TECHNICAL, SCIENTIFIC, BUSINESS and MANAGEMENT SPECIALISTS

- 115 EAST 23RD STREET, NEW YORK, N.Y. 10010

- WINTER PARK MALL, WINTER PARK, FLORIDA 
ence services. She anticipated that these services will be expanded next year following NAL's removal into its new $\$ 7.5$ million building. NAL, she explained has recently established several clearinghouses and cooperative arrangements in certain specific areas. An extensive automation program is now being planned for NAL's operations and services.

Mr. Adams pointed out that the mission of the National Library of Medicine is "to assist in the development of the medical and health sciences." He explained that this is interpreted currently to mean that NLM functions as a backstop to a loosely knit decentralized network of libraries serving the needs of the medical community. It furnishes interlibrary loans and photocopies, and it publishes Index Medicus and other bibliographic publications produced from the same computer base. There is also an extensive audio-visual program under the purview of NLM. Its MEDLARS search program, which is rapidly being decentralized to university libraries throughout the land, is now conducting some four hundred demand searches monthly. Under provisions of the Medical Library Assistance Act of 1965, the NLM makes construction grants, supports intern and other training programs, sponsors research and publication, and encourages regional medical libraries. In closing Mr. Adams described current cooperative efforts of NAL, NLM, and LC, and stated that continuing effort was being made to eliminate unnecessary duplication of services and as far as possible to maintain compatible machine systems.

Dr. Shank reviewed the venerable and impressive history of library activities in the

ACRL Membership, November 30, 1967 12,658

$$
\text { November 30, } 1966 \text { 11,220 }
$$

College Libraries Section, November 30, 1967

Junior College Libraries, November 30, 1967

Rare Books Section, November 30, 1967

Subject Specialists Section, November 30, 1967

1,474

University Libraries Section, November 30,1967

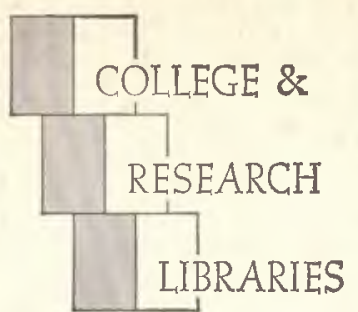

ACRL News Issue of College \& Research Libraries

Editor, David Kaser, Joint University Libraries, Nashville, Tenn. 37203.

Publications Officer, Mary Falvey, $50 \mathrm{E}$. Huron St., Chicago 60611.

ACRL Executive Secretary, George M. Bailey.

ACRL Officers, 1967/68: President, James Humphry III; College Libraries Section Chairman, Audrey North; Junior College Libraries Section, Mrs. Alice B. Griffith; Rare Books Section, Lawrence S. Thompson; Subject Specialists Section, Richard L. Snyder; Agriculture and Biological Sciences Subsection, Mrs. Pauline W. Jennings; Art Subsection, James K. Dickson; Law and Political Science Subsection, Morris Cohen; Slavic and East European Subsection, Jerzy (George) J. Maciuszko; University Libraries Section, Stuart Forth.

Editorial Board: John M. DAwson, University of Delaware; Gustave A. Harken, Boston University; SaMuel Rothsten, University of British Columbia; James E. Skupper, Princeton University; Norman E. Tanis, Kansas State College of Pittsburg; Mauruce F. Tauber, Columbia University; Emlen Thornton, Oberlin College.

News from the Field, Personnel profiles and notes, classified advertising, official matter of ACRL, and other material of a timely nature is published in the News issues of College \& Research Libraries.

Inclusion of an article or advertisement in CRL does not constitute official endorsement by ACRL or ALA.

Production and Advertising and Circulation office; 50 E. Huron St., Chicago, Ill. 60611, Change of address and orders for subscriptions should be addressed to College of Research Libraries, for receipt at the above address, at least two months before the publication date of the effective issue.

Subscription to $C R L$ is included in membership dues to $A C R L$ of $\$ 6$ or more; other subscriptions to CRL are $\$ 10$ per year. Neither subscriptions nor memberships include miscellaneous unscheduled supplements, which are available by purchase only. Retroactive subscriptions are not accepted. Single journal copies are available at $\$ 1.50$ each and News issues at $\$ 1.00$ each from ALA Publishing Department.

Indexed in Library Literature. Abstracted in Library Science Abstracts. Book reviews indexed in Book Review Index.

College \& Research Libraries, is the official journal of the Association of College and Research Libraries, a division of the American Library Association; and is published seventeen times per year-bi-monthly as a technical journal with 11 monthly News issues, combining July-August - at 1201-05 Bluff St., Fulton, Mo. 65251 .
Second-cless postage paid at Fulton, Mo. and at additional mailing offices. 
Smithsonian Institution. He stated that more than a million volumes have been received in the Smithsonian library and then forwarded, because of their inappropriate subject matter, to one of the national libraries. The Smithsonian, however, has retained some eight hundred thousand volumes, which it maintains decentrally throughout the Institution. Although it is not truly a national library, the Smithsonian keeps its books with the national collections of objects, artifacts, and specimens, which it is responsible for curating, and thereby renders a national service. There is limited library staff and control, although the libraries operate much in the fashion recommended in the Weinberg Report. The output of the curators themselves is the major bibliographic service of the Institution, although the library does render interlibrary and mail-order reference services, and it welcomes visiting scholars. Dr. Shank observed that the Institution carries on a vast publications exchange program of its own in addition to operating the International Exchange Service.

Following a vigorous question-and-answer period, the group adjourned for lunch and reconvened at 1:30 PM. The afternoon session concerned "Potential Services to College and Research Libraries." It featured Bernard Fry, now dean of the graduate school of library service at Indiana University, who told of the Clearinghouse for Scientific and Technical Information which he had formerly directed; Howard B. Lawson, who described the services of the Defense Documentation Center as chief of its Liaison Coordination Division; Monroe Freeman, director of the Science Information Exchange, related the work of his group; and Dale B. Baker, director of Chemical Abstracts Services spoke of the national chemical information services.

Dean Fry explained that the Clearinghouse is a system for supplying research and development information to a wideranging public which is not limited to the glamorous, space-age industries with which it is associated in many people's minds. $\mathrm{He}$ indicated that need for the clearinghouse was recognized following World War II, but that it was unable to launch extensive programs until recent years. The clearinghouse operates five programs: (1) document distribution and sales; (2) research in progress; (3) services to local systems;
(4) referral; and (5) reference and bibliographic services. The clearinghouse processes some sixty thousand documents annually, of which about twenty thousand are technical translations, and forty thousand are R \& D reports. These documents are not selected but are brought together, indexed, abstracted, and listed for distribution, Dean Fry explained.

Mr. Lawson reminded that the Defense Documentation Center is the successor to ASTIA, which had grown out of the need to collect and organize captured German and Japanese technical literature following World War II. It now operates a computerbased data bank of basic technical and management data to indicate who is doing what, when, where, and how in order again to eliminate the unnecessary duplication of effort. The services of the DDC are furnished free to the defense establishment, to its related agencies, and to their many contractors and subcontractors. Its unrestricted services are made available to others on a cost basis. It publishes both the U.S. Government Research \& Development Reports and the Technical Abstracts Bulletin, and it supplies computer-produced bibliographies either from stock or individually tailor-made on demand. Mr. Lawson said that the DDC is currently receiving approximately seven thousand requests daily for documents, either in microform or in hard copy.

Mr. Freeman explained that the Science Information Exchange, which operates out of the Smithsonian Institution, acts primarily as a clearinghouse for scientific information, and it maintains an inventory of research in progress. Some one hundred twenty thousand reports annually are submitted by a multiplicity of agencies and individuals, both in the government and in the private sector. An average of thirty units of information is identified on each, and these data are coded for machine manipulation. The rapid obsolescence of the data necessitate its prompt handling. This activity began twenty years ago based upon manual files, but it was shifted to a computer base a decade ago.

Dr. Baker explained the mission of the CAS on freeing up the transfer of chemical literature so that the efficiency of chemists can be improved. CAS now employs some three thousand three hundred abstractors, (Continued on page 20) 
University of North Carolina library, Chapel Hill.

EmIL Schafer has been appointed systems analyst in the University of Southern California library.

D. W. Schnieder is now chief of the business administration and social sciences division in University of North Carolina library, Chapel Hill.

LOUTS SHORES, dean emeritus of the library school, Florida State University is the newly named director of the TEX-TEC PROJECT for the Communication Service Corporation of Washington, D.C. under the terms of a contract recently signed with the Texas state library. Dr. Shores will head a team of library and education consultants preparing syllabi for library technician courses to be taught in Texas Junior Colleges.

Mrs. Barbara Silver has accepted the position of cataloger at the University of California, Santa Barbara.

MARTIN SILvER was named music librarian at the University of California, Santa Barbara, to take charge of the music section of the arts library scheduled to open in 1968 .

Robert Sivers has been serving as map librarian for the past six months in the sciencesengineering library, University of California, Santa Barbara.

Mrs. Juliann Skurdenis-Smircich has been named head of acquisitions in Pratt Institute library.

IRVING K. SMITH, former serials librarian at Florida Atlantic University, has assumed the new position of science librarian at Indiana State University, Terre Haute.

SANDRA SMITTLE transferred Nov, 1 from her position as international documents librarian at the UCLA Library to the UC Santa Barbara government publications section, where she will be in charge of the federal documents depository.

Mrs. Yun Song has been appointed cataloger and advisor to the LC reclassification project at Wichita State University.

HARVEY Soule is the new education librarian in Kent State University.

Davio H. Stam is now head of the processing department of the Newberry library, Chicago.

In Feb. Ralph E. Stirewalt, Ford Foundation consultant to the Haile Selassie I University library in Ethiopia, will become coordinator of technical services at Wichita State University.

Leslie Armour Taylon is now head of technical services in Hunter College library, Park Ave., New York.

Mary Lynwood Thaxton has been appointed assistant reference librarian, Earl Gregg Swem library, College of William and Mary.

IAN W. Thom has been appointed associate librarian, Paul Klapper library, Queens College of the City University of New York.
Mrs. Sharon C. Thomas has joined Trinity University as head of acquisitions.

On Aug. 1, Donald Thompson joined the social science/business library staff in Southern Illinois University, Edwardsville.

Marguertie Joyce Thompson has been appointed head of the cataloging department, University of Iowa libraries.

Mrs. Irene Silver Topalcic is serials cataloger in Hunter College library, Park Ave., New York.

GeORge Toussaint was named assistant social science librarian of Southern Illinois University, Edwardsville, on Oct. 23.

Mrs. Helen UrquHart is a new staff member in the catalog department of University of of North Carolina library, Chapel Hill.

Seymour Weinstein has been appointed head of the circulation department, University of Iowa libraries.

RAY WILE is supervisor of evening services in Paul Klapper library, Queens College, City University of New York.

Mrs. Elizabeth WiLliams is assistant documents librarian, University of North Carolina, Chapel Hill.

RUBy O. Woons has joined the staff of Sacramento State College library as assistant education \& psychology reference librarian.

Vincent KUO-Chen $\mathrm{YU}_{\mathrm{U}}$ is a cataloger in Hunter College library, Park Ave., New York.

\section{FIFTY-THIRD CONFERENCE}

(Continued from page 4)

and for each abstract it publishes CAS uses some twenty-eight index entry points. Although CAS has had grants for research and development, its production has always been self-supporting. It has four kinds of output: (1) awareness of alerting tools; (2) search tools; (3) correlative tools; and (4) specialized custom services tailored to demand. He indicated that CAS is anxious to improve its communication with the library community and is taking steps to accomplish it. His organization is now developing a list of the holdings of most of the large libraries of the major sources of chemical literature, including twenty-four thousand serial entries and thirty-four hundred monographic entries. This union list is almost complete and will constitute a major service.

Again vigorous discussion ensued, following which the group repaired to an upper floor for a reception and refreshments before adjourning for another year.-DK 